\title{
CTR9 Gene
}

National Cancer Institute

\section{Source}

National Cancer Institute. CTR9 Gene. NCI Thesaurus. Code C118340.

This gene is involved in embryonic stem cell pluripotency, transcriptional elong ation and histone modification. 